\title{
Home purchase restriction, real estate investment, and corporate innovation
}

\author{
Weida Kuang ${ }^{1}$, Changyu Chen ${ }^{1 *}$ and Qilin Wang ${ }^{2}$
}

\author{
* Correspondence: chency620@163. \\ com \\ ${ }^{1}$ Department of Finance, Business \\ School, Renmin University of China, \\ 59 Zhongguancun Street, Haidian \\ District, Beijing 100872, China \\ Full list of author information is \\ available at the end of the article
}

\begin{abstract}
It is ubiquitous for non-real estate firms to conduct real estate business in China. Home purchase restriction (HPR) affects corporate innovation by dampening the real estate investment of non-real estate firms. The extant literature has examined the impact of HPR on corporate innovation, but it has not focused on the expectation of HPR and the endogeneity problem. Employing a dataset of 1830 listed non-real estate firms over the period 2009-2016, this research explores the expectation of HPR on corporate innovation based on the motivations for real estate investment in non-real estate firms. We demonstrate that HPR facilitates the enhancement of research and development (R\&D) investment in non-real estate listed firms by hindering real estate investment, particularly for non-high-tech firms. The effects of HPR arrive at the crest in the third implementation year and remain steady thereafter. The real estate investment of non-real estate firms rebounds and the R\&D investment declines along with the cancellation of HPR. Tackling the selection bias and endogeneity problems, the baseline results are also robust. Hence, HPR should serve as a long-term vehicle to improving corporate innovation, in addition to preventing housing speculation.
\end{abstract}

Keywords: Home purchase restriction (HPR) expectation, Real estate investment, Nonreal estate firms, Corporate innovation

\section{Introduction}

Non-real estate firms involved in the real estate business are ubiquitous and pervasive in China, which account for roughly $42 \%$ of non-real estate firms listed in China's Shanghai and Shenzhen stock exchanges during the period 2009-2016, in keeping with Liu and Guan (2019), Meng et al. (2018), and Rong and Wang (2014). ${ }^{1}$ In addition, real estate investment is widespread in various industries in China. Aside from Monetary and Financial Services (J66) and Real Estate (K70), 71 out of 75 industries conduct real estate business, which equates to $94.67 \%$ in China's Shanghai and Shenzhen stock exchanges during the period 2009-2016. Moreover, 25 industries exist, for which the proportion of listed non-real estate firms involved in the real estate business is over $60 \%$. In particular, Chinese listed firms play a predominant role in China's economy. According to the China Securities and Futures Statistical Yearbooks and China Statistical Yearbooks, the market

\footnotetext{
${ }^{1} \mathrm{~A}$ non-real estate firm involves in real estate business if it reports investment in real estate and real estate operation income in the annual report.

(c) The Author(s). 2020 Open Access This article is licensed under a Creative Commons Attribution 4.0 International License, which permits use, sharing, adaptation, distribution and reproduction in any medium or format, as long as you give appropriate credit to the original author(s) and the source, provide a link to the Creative Commons licence, and indicate if changes were made. The images or other third party material in this article are included in the article's Creative Commons licence, unless indicated otherwise in a credit line to the material. If material is not included in the article's Creative Commons licence and your intended use is not permitted by statutory regulation or exceeds the permitted use, you will need to obtain permission directly from the copyright holder. To view a copy of this licence, visit http://creativecommons.org/licenses/by/4.0/.
} 
capitalization of the listed firms accounts for $58.01 \%$ of GDP on average during 20092016. Hence, whether non-real estate firms should conduct real estate business is a controversial topic within policy-makers, academic, and industrial circles. Since the housing system reform in 1998, the real estate industry has gradually grown into one of the most important pillar industries in China. According to the China Statistical Yearbook 2018, the added-value of the real estate industry accounts for 7.0\% of GDP in 2017. As China's economic growth enters a period of decelerating, the return on the real economy decreases, while house prices continue to rise. This leads to the notice of resolutely restraining the excessive rise of house prices in some cities issued by the State Council of China in 2010. Since then, to prevent the real estate market from overheating, the first- and second-tier cities have gradually implemented home purchase restriction (HPR).

It is imperative to disentangle how HPR affects corporate real estate and innovation investments. Unfortunately, the extant research concentrates on the impact of HPR on housing demand but neglects the supply of housing. In essence, how HPR affects real estate development decisions is also crucial to housing market equilibrium (Wang and Huang 2013). In other words, the response of developers to HPR decides the policy implementation effects. Hence, this research seeks to detect the effects of HPR on the real estate investment and innovation investment of non-real estate firms. The proportion of real estate investment in non-real estate firms declined in 2010 and 2011 but rebounded in 2014 and 2015 in the sense that some cities canceled HPR in 2014 and 2015. As a result, HPR plays a pivotal role in mediating the real estate investment of non-real estate firms. This research fills the gap in the mechanism of HPR on the real estate and innovation investments of non-real estate firms. Meanwhile, this research provides evidence for policymakers to evaluate the spillover effects of HPR on non-real estate firms to improve corporate innovation.

In general, a firm's main business is the key to determining its competitiveness. More importantly, the research and development $(\mathrm{R} \& \mathrm{D})$ investment is vital to improving the main business of a firm and the entire economic growth in the long run. Apparently, the financing capability and capital occupation of real estate investment in non-real estate firms could affect their R\&D investments. In July 2014, the executive meeting of the State Council of China proposed, for the first time, provoking more credit funds from the virtual economy to the real economy. Nevertheless, according to the China Financial Stability Report 2017, released by the People's Bank of China, the outstanding balance of new real estate lending accounted for $44.8 \%$ of overall new loans in 2016. Therefore, regulating the speculative bubble is the core goal of housing policies. In essence, whether the real estate investment is in the real economy or the virtual economy lies in the dual attributes of assets and capital inherent in real estate investment. In terms of the capital attribute, the real estate investment of non-real estate firms serves as collateral and facilitates improving financing ability, thus improving their main business and R\&D investment. By contrast, in terms of asset attributes, the real estate investment of non-real estate firms is ascribed to the investment motivation, which will undermine their main business and R\&D investment.

Accordingly, the real estate investment of non-real estate firms normally has two contrasting effects of financing and investment motivations. Under the financing motivation, the non-real estate firms enhance their financing capability through the collateral effects of real estate investment, which satisfies the capital demand of innovation activities and promotes main business development. Under the investment motivation, the 
real estate investment of non-real estate firms augments the short-term profit and sacrifices the long-term profit due to the wealth effect of real estate investment. Thereby, the pursuit of short-term profit in real estate investment will reduce $R \& D$ investment and ultimately violate the long-term development of non-real estate firms. In other words, the financing motivation is conducive to escalating the R\&D investment in nonreal estate firms, whereas the investment motivation has adverse effects.

Based on the contrasting motivations for real estate investment in non-real estate firms, this research attempts to exploit how HPR affects the R\&D investment of nonreal estate firms. As mentioned above, the previous literature has examined the impacts of house price, real estate investment, and HPR on corporate innovation (Chen et al. 2016; Hu et al. 2019; Wang and Huang 2013; Yu and Zhang 2017), with little involvement in the effects of HPR expectation on corporate innovation and the endogeneity problem between real estate investment and corporate innovation. Furthermore, as previous studies do not consider the motives for the real estate investment of non-real estate firms, they fail to reveal the mediating mechanisms of HPR.

This research utilizes the dataset of 1,830 non-real estate listed firms in the Shanghai and Shenzhen exchange markets over the period 2009-2016 to explore the mediating mechanism of HPR and the impacts of HPR expectation on corporate innovation. First, this paper documents that the real estate involvement in non-real estate firms is driven by investment motivation, which significantly crows out innovation investment. It suggests that HPR is able to facilitate corporate innovation by dwarfing real estate involvement in non-real estate firms. Second, the expectation of HPR positively affects the $R \& D$ investment in non-real estate firms, which first intensifies and then stabilizes. That is, HPR has lagging and overlapping effects and becomes steady later. Third, the real estate investment of non-real estate firms rebounds and innovation investment decreases in the wake of the cancellation of HPR. Last, taking residential land area as an instrument vehicle of HPR, the baseline results are proved to be robust.

This research contributes to the extant literature in three regards. First, the previous studies do not take into account the expectation and externality of HPR (Cao et al. 2015; Du and Zhang 2015; Hu et al. 2019; Meng et al. 2018; Yu and Zhang 2017); this research introduces the duration of HPR to gauge the expectation and spillover effects of HPR and explores the externality and spillover effects of HPR on corporate innovation. Second, the preceding works measure HPR and corporate real estate investment based on corporate headquarters (Hu et al. 2019; Meng et al. 2018; Yu and Zhang 2017); this research improves the weighted measurement of HPR by proposing a spatial weight matrix of real estate business to capture the overall effects of HPR in various cities on a firm's subsidiaries. Third, this research employs the residential land area as an instrument vehicle of HPR to resolve the endogeneity problem, which is not well addressed in the previous literature (Chen et al. 2016; Hu et al. 2019; Wang and Huang 2013).

The remainder of this research proceeds as follows. Section 2 provides a brief literature review. Section 3 introduces the data and methodology strategy. Section 4 presents the baseline results on how HPR affects corporate innovation in non-real estate firms. Section 5 adopts the Probit model, two-stage least squares (2SLS) estimation, and the propensity score matching and difference-in-differences (PSM-DID) approach to conduct robustness checks. The final section includes concluding remarks and policy implications. 


\section{Literature review}

\section{Real estate investment and corporate innovation}

Over the past two decades, the housing market in China has seen rapid growth. From 2000 to 2010, the average real-term annual growth rate of house prices in China's 35 major cities was nearly 9\% (Wu et al. 2012). The rising consumption demand for housing due to population growth is one of the primary factors in the rise of house prices in China (Wang 2013). However, the abnormal increase in the house price index is mainly driven by demand from domestic and foreign capital investment. Liu (2008) finds that the approximate $20 \%$ rise in the house price index from 2000 to 2006 can be explained by the foreign hot money flowing into the Chinese market. The consumption demand for housing (Zhang et al. 2011) and the speculative demand due to real estate price appreciation expectations (Han and Zhao 2011) have gradually become the key factors governing house price trends in China. Kuang et al. (2020) prove that the expected house prices significantly interact with the current household savings.

In terms of investment motivation, Chen and Wang (2013) demonstrate that the real estate myth is a main factor hindering economic restructuring and industrial upgrading. Luo and Zhang (2015) argue that the increase in real estate investment impairs the resource allocation efficiency of the manufacturing sectors. Similarly, Zhang et al. (2016) use provincial-level panel data to show that the provinces with faster real estate investment growth have lower growth rates for innovation input and output. Rong et al. (2016) verify that manufacturing firms diversify into the real estate industry, normally for speculative reasons, and a firm's invention patents are negatively influenced by its real estate diversification. Shi et al. (2016) argue that Chinese firms reduce their R\&D expenditures and patents in a hot real estate market, which could be partially explained by managerial myopia.

In terms of the financing motivation, real estate, as valuable collateral, can enhance the debt capacity of enterprises. Gan (2007) finds that the exogenous shock caused by the land market collapse in Japan reduces firms' collateral value and thus their borrowing capacities, which in turn translates into lower investment rates. Chaney et al. (2012) elucidate that when there is financing friction, the rise in local house prices can promote investment activities through the collateral effect of a residential mortgage. Furthermore, innovation investment, as an important investment behavior, will also be affected by real estate investment. Cao et al. (2014) prove that positive shocks to the value of real estate collateral enhance firms' financing capacity and lead to more innovation through the collateral channel, and such a positive effect is persistent over the subsequent 5 years. Miao and Wang (2014) designate a real estate bubble as a sectoral bubble, which can improve investment efficiency through the credit easing effect and crowd out the investment of other sectors through the capital reallocation effect. Mao (2017) also finds that higher real estate collateral value increases the quantity, quality, and novelty of innovation.

In sum, the previous research has not reached a consensus on how real estate investment affects corporate innovation. In essence, the motives of non-real estate firms investing in real estate are complex and difficult to ascertain, which will result in differential 
innovation activities and outcomes. The investment motivation of real estate investment of non-real estate firms crows out corporate innovation investment. The financing motivation, however, mitigates and improves the financing ability through the collateral effect of a real estate mortgage, which facilitates innovation investment in non-real estate firms.

\section{Home purchase restriction and real estate investment}

A variety of housing market regulations have been successively enacted and issued since 2010, such as the HPR, which limits the number of houses a resident can buy (Zhang et al. 2019). Yu and Zhang (2017) take the announcement of HPR as a shock and find that those policies alleviate the impact of house price rises on innovation activities by curbing real estate over-investment. Chen et al. (2016) find that the prosperity of the real estate market increases land investment, especially in commercial land, but reduces non-land investment through the mortgage effect and crowding-out effect of real estate prices. The rising real estate prices lead to resource mismatch, and the HPR has a significant effect on reducing commercial land investment and increasing non-land investment. Hu et al. (2019) verify that the HPR not only deters the investment in real estate but also encourages non-real estate firms to focus on the main business and increase innovation investment.

The HPR aims to regulate demand in the housing market, particularly the demand for investment and speculation. The market price is the equilibrium between supply and demand. As the supplier of the real estate market, the developers' response to the HPR will affect the implementation efficiency of the HPR in the long run. Wang and Huang (2013) propose that the HPR reduces the speed of fund recovery and increases the repayment pressure of developers. Thereby, the HPR might reduce house prices and housing supply. Unfortunately, the extant literature focuses on the effects of the HPR on housing demand but neglects housing supply.

Due to the heterogeneous responses of market participants, this research verifies that the short-term effects of the HPR are mainly decided by the housing demander. In the short term, the HPR will reduce the housing investment of investors or speculators. In the long run, the HPR will deter real estate developers from undertaking housing development, and curtail housing supply based on the construction cycle. Thus, in the long run, the HPR not only depress the investment or speculation demand for housing but also weaken the financing capability through the collateral effect of housing mortgages and reduce the supply of housing. As a result, the longer the HPR duration, the less real estate investment in non-real estate firms.

\section{The expectation of home purchase restriction and corporate innovation}

The effects of the HPR on corporate innovation are reflected both in the short run and in the long run, due to the heterogeneous responses of market agents. On the one hand, there exists uncertainty when a new policy is enacted and published. Du and Zhang (2015) utilize counterfactual methods to measure the impact of the HPR on house prices in Beijing. They find that the HPR significantly reduces house prices, but the policy effect reaches the climax 1 year later, which indicates that the HPR has a time lag. Shah and Ghonasgi (2016) also point out that the impact of monetary policy shocks on consumer prices arrive at the apex 2 months later. Ruiz and Vargas-Silva 
(2016) use vector autoregression models to study the impact of fiscal policy on the U.S. real estate market and find that the budget spending expansion policies both influence real estate transactions in the short term and affect house prices in the long term.

On the other hand, a strand of literature documents that expectation stability affects policy efficacy. Policy instability causes market participants to shape unstable expectations and violate the policy (Barro 1991; Benhabib and Spiegel 1994). Krugman (1998) argues that the public will reinforce their expectations of inflation and successfully circumvent the economic liquidity trap should they believe expansionary monetary policies are not temporary. Tomura (2010) and Burnside et al. (2016) argue that unstable expectation results in the real estate cycle. In addition, expectation management can improve the stability and effectiveness of policy implementation (Morris and Shin 2002, 2008). Bernanke (2013) believes that expectation management effectively accelerates economic recovery in the event that the normal interest rate is required to be not less than zero. Campbell et al. (2012) corroborate that expected management improves policy efficiency. Kuang (2010) documents that house price volatility is determined by the economic fundamentals rather than the expectation and speculation, but the latter has strong explanatory power on urban house price volatility in China. Liu et al. (2012) contend that the HPR is helpful in reducing the current house prices, but that canceling the policy in the short term will lead to a retaliatory rebound of house prices. The long-term house price trend is related to the duration and strength of the HPR, whilst the stable expectation of developers and investors is vital to governing the trend of house prices in the housing market. Wang and Huang (2013) find that if the HPR is short-term and the developers expect that the house prices will go up after the cancellation of the HPR, the expectation of arbitrage is shaped. Cao et al. (2015) employ a two-stage DID model to testify the HPR effect. They find that the housing price, on average, dropped by $18.3 \%$ after the HPR implementation, whilst the trend of property investment and development does not alter.

In essence, the expectation formation is highly correlated with the duration of the HPR. Unfortunately, the previous literature does not examine the expectation and long-term overlapping effects of the HPR on corporate innovation. Hence, this research predicts that the impact of the HPR on real estate investment in non-real estate firms will first reinforce and then remain steady over time. Therefore, to alleviate the crowding-out effect of real estate investment on corporate innovation, the duration of the HPR should be longer under the investment motivation. In contrast, under the financing motivation, the longer the duration of the HPR, the less the collateral effect, and the less the corporate innovation investment. In other words, policymakers should trade off the benefit and cost of the HPR considering the motivations of real estate investment in non-real estate firms.

\section{Empirical study \\ Data}

We utilize the corporate innovation dataset of 1830 non-real estate and non-financial firms listed in China's Shanghai and Shenzhen stock exchange markets during the period 2009-2016. According to the industry classification issued by the China Securities Regulatory Commission in 2012, there are 90 industry categories; our samples cover 75 industries due to data availability. The listed firms with $R \& D$ investment in our samples refer to 74 industries, which account for $82.22 \%$ of the 90 industry categories. Thereby, R\&D 
investment is a universally important decision for Chinese listed firms. The samples of corporate headquarters and subsidiaries graphically distribute across China's 266 cities. The firm-level data are from CSMAR and Wind databases, while the city-level data are gathered from China Urban Construction Statistical Yearbooks. The implementation and cancellation of the HPR pertaining to the sample cities are collected from local government websites and the relevant official documents.

\section{Econometric setup}

In order to verify the mediating mechanism of the HPR on corporate innovation, this research constructs the following mediation models following relevant research (Quan and Yin 2017; Wang and Zhao 2015; Wang and Zhu 2018; Yu and Zhang 2017).

$$
\begin{aligned}
& R D_{i t}=\alpha_{0}+\alpha_{1} R E_{i t}+\alpha_{2} \text { Size }_{i t}+\alpha_{3} L E V_{i t}+\alpha_{4} \text { Growth }_{i t}+\alpha_{5} R O A_{i t}+\alpha_{6} \text { Top }_{i t}+\alpha_{7} \text { State }_{i t} \\
& +\alpha_{8} \text { Industry }_{i t}+\alpha_{9} \text { Firm }_{i}+\alpha_{10} \text { Year }_{t}+\varepsilon_{i t} \\
& R E_{i t}=\beta_{0}+\beta_{1} H P R_{i j t}+\beta_{2} \text { Size }_{i t}+\beta_{3} L E V_{i t}+\beta_{4} \text { Growth }_{i t}+\beta_{5} R O A_{i t}+\beta_{6} \text { Top }_{i t}+\beta_{7} \text { State }_{i t} \\
& +\beta_{8} \text { Industry }_{i t}+\beta_{9} \text { Firm }_{i}+\beta_{10} \text { Year }_{t}+\omega_{i t} \\
& R D_{i t}=\rho_{0}+\rho_{1} H P R_{i j t}+\rho_{2} \text { Size }_{i t}+\rho_{3} L E V_{i t}+\rho_{4} \text { Growth }_{i t}+\rho_{5} R O A_{i t}+\rho_{6} \text { Top }_{i t}+\rho_{7} \text { State }_{i t} \\
& +\rho_{8} \text { Industry }_{i t}+\rho_{9} \text { Firm }_{i}+\rho_{10} \text { Year }_{t}+\vartheta_{i t} \\
& R D_{i t}=\tau_{0}+\tau_{1} H P R_{i j t}+\tau_{2} R E_{i t}+\tau_{3} S_{i z e_{i t}}+\tau_{4} L E V_{i t}+\tau_{5} \text { Growt }_{i t}+\tau_{6} R O A_{i t}+\tau_{7} T o p 5_{i t} \\
& +\tau_{8} \text { State }_{i t}+\tau_{9} \text { Industry }_{i t}+\tau_{10} \text { Firm }_{i}+\tau_{11} \text { Year }_{t}+\mu_{i t}
\end{aligned}
$$

In the above models, $R D_{i t}$ denotes the R\&D investment of firm $i$ at year $t, R E_{i t}$ denotes the real estate investment of firm $i$ at year $t, H P R_{i j t}$ represents the implementation of an HPR policy of city $j$ at year $t$ where the headquarter of firm $i$ resides, and the control variables include firm size $\left(\right.$ Size $\left._{i t}\right)$, debt ratio $\left(L E V_{i t}\right)$, growth $\left(G^{\prime} r o w t h_{i t}\right)$, asset return $\left(R O A_{i t}\right)$, corporate governance $\left(T o p 5_{i t}\right)$, and firm nature $\left(\right.$ State $\left._{i t}\right)$. In addition, all of the above models control for the industry-fixed effects, firm-fixed effects, and yearfixed effects. Finally, the standard errors are clustered at the firm level.

Model (1) is used to testify the impact of real estate investment on innovation investment in non-real estate firms and distinguish the motivation for the real estate investment in the non-real estate firms. If the financing motivation is proved, the real estate investment in the non-real estate firms is conducive to providing financing support for corporate innovation activities. As such, $\alpha_{1}$ should be significantly positive. By contrast, the investment motivation is verified if $\alpha_{1}$ is significantly negative, and the real estate investment in the non-real estate firms will crowd out the innovation investment.

Model (2) aims to explore the impact of the HPR on the real estate investment in non-real estate firms. This research predicts that the HPR dwarf the real estate investment in the non-real estate firms; thus, $\beta_{1}$ in Model (2) ought to be significantly negative. 
Model (3) attempts to testify the overall impact of the HPR on corporate innovation. The model focuses on the economic significance and statistical significance of $\rho_{1}$. The HPR could effectively advance corporate innovation if $\rho_{1}$ is significantly positive, and vice versa.

Model (4) identifies the mediating mechanism of real estate investment in non-real estate firms between the HPR and corporate innovation. The assumption of the mediation model is that $\alpha_{1}$ in Model (1) and $\beta_{1}$ in Model (2) are both statistically significant. As such, if $\tau_{2}$ in Model (4) is statistically significant and the economic significance and statistical significance of $\tau_{1}$ in Model (4) are weaker than $\rho_{1}$ in Model (3), the indication is that real estate investment has a partial mediating effect on corporate innovation. If the economic significance and statistical significance of $\tau_{1}$ in Model (4) do not exist, real estate investment has a full mediating effect on corporate innovation.

In addition to the overlapping effects of the HPR, this research also investigates the lagged effects of the HPR on corporate innovation. According to Zhou et al. (2013), this research creates the HPR duration variable $H P R_{-} S_{i j t}$. That is, if the HPR policies are implemented in the $N^{\text {th }}$ year, the value of $H P R \_S_{N_{i j t}}$ is 1 , and otherwise 0 . Hence, we add the 7 year-dummy variables of the HPR implementation into Models (5) and (6) as follows.

$$
\begin{aligned}
& R E_{i t}=\gamma_{0}+\gamma_{1} H P R S_{1_{i j t}}+\gamma_{2} H P R S_{2_{i j t}}+\gamma_{3} H P R S_{3_{i j t}}+\gamma_{4} H P R S_{4_{i j t}}+\gamma_{5} H P R S_{5_{i j t}}+\gamma_{6} H P R S_{6_{i j t}} \\
& +\gamma_{7} H P R \_S_{7_{i j t}}+\gamma_{8} \text { Size }_{i t}+\gamma_{9} L E V_{i t}+\gamma_{10} \text { Growth }_{i t}+\gamma_{11} R O A_{i t}+\gamma_{12} \text { Top }_{i t} \\
& +\gamma_{13} \text { State }_{i t}+\gamma_{14} \text { Industry }_{i t}+\gamma_{15} \text { Firm }_{i}+\gamma_{16} \text { Year }_{t}+\xi_{i t} \\
& R D_{i t}=\lambda_{0}+\lambda_{1} H P R \_S_{1_{i j t}}+\lambda_{2} H P R \_S_{2_{i j t}}+\lambda_{3} H P R \_S_{3_{i j t}}+\lambda_{4} H P R \_S_{4_{i j t}}+\lambda_{5} H P R \_S_{5_{i j t}}+\lambda_{6} H P R \_S_{6_{i j t}} \\
& +\lambda_{7} H_{P R} S_{7_{i j t}}+\lambda_{8} \text { Size }_{i t}+\lambda_{9} L E V_{i t}+\lambda_{10} \text { Growth }_{i t}+\lambda_{11} \text { ROA }_{i t}+\lambda_{12} \text { Top }_{i t} \\
& +\lambda_{13} \text { State }_{i t}+\lambda_{14} \text { Industry }_{i t}+\lambda_{15} \text { Firm }_{i}+\lambda_{16} \text { Year }_{t}+\psi_{i t}
\end{aligned}
$$

In Models (5) and (6), the coefficients of the year-dummy variables $H P R S_{N_{i j t}}$ stand for the lagged effects of the HPR on the real estate investment and R\&D investment in the non-real estate firms across the implementation years. Thereby, we focus on the economic significance and statistical significance from $\gamma_{1}$ to $\gamma_{7}$ in Model (5) and from $\lambda_{1}$ to $\lambda_{7}$ in Model (6). We predict that these coefficients are significantly positive but vary across the HPR implementation years.

\section{Variable and descriptive analysis}

As the corporate innovation cycle varies across firms and industries, this research employs innovation input (e.g., R\&D expenditure) rather than innovation output (e.g., patents) to represent corporate innovation. Unlike traditional wisdom, this research adopts two ways of measuring the duration of the HPR. ${ }^{2}$ One way is to compute consecutive years of the HPR. The other way is to weigh the consecutive years of the HPR with real estate income ratios between a firm's headquarter and its subsidiaries, then accelerate the

\footnotetext{
${ }^{2} \mathrm{Yu}$ and Zhang (2017) use the DID method to investigate the impact of the HPR on corporate innovation, but fail to tackle the random problem of the HPR and the selection bias of samples. Accordingly, this research first adopts the PSM model to match the treatment group and control group, then takes the DID method to estimate the peer-matched group. The results are available in robustness checks.
} 
duration of the HPR with the sum-of-the-years'-digits method. The mediator variable is the real estate investment in non-real estate firms. In accounting terms, corporate real estate income and $R \& D$ investment are corporate current revenue and expenditure, respectively, whereas investment real estate refers to corporate assets. Hence, to coincide with $R \& D$ investment, we employ corporate real estate income to measure real estate investment. Table 1 describes the definitions and metrics of the majority variables.

Table 2 exhibits that the standard deviation of R\&D investment is 1.6401, which indicates that $R \& D$ investment varies vastly across firms. The standard deviation of real estate income is 4.0551, which also implies that real estate income differs substantially across firms. The maximum HPR duration is seven years and the minimum is zero, with a standard deviation of 0.7593. Likewise, the maximum weighted HPR duration is 0.9722 and the minimum is 0 , with a standard deviation of 0.1521 . Thus, the dispersion of the HPR duration is trivial.

Figure 1 plots the sharp increase in the growth rate of R\&D investment after the HPR has been implemented. Obviously, the R\&D investment of non-real estate firms in the cities with the HPR is significantly higher than that in the cities without an HPR. In 2010, Beijing took the lead in announcing the HPR, and then 42 cities released the HPR in 2011. In order to distinguish the disparities of R\&D investment of Chinese listed non-real estate firms between the cities with and without the HPR, it is necessary to conduct peer matching. It is noteworthy that due to the differentials in economic development and population scale, it is unlikely to match the four first-tier cities (i.e., Beijing, Shanghai, Shenzhen, and Guangzhou) with the other large- and medium-sized cities effectively. Therefore, we have to remove the samples of the four first-tier cities. Based on urban house prices, population density, and disposable income per capita, we match the remaining cities with and without the HPR. Figure 1 depicts that the R\&D investment of Chinese listed non-real estate firms in the cities without the HPR increased steadily from 2009 to 2012. By contrast, the R\&D investment of Chinese listed non-real estate firms in the cities with the HPR was flat prior to the implementation but increased dramatically after. Hence, the HPR policies fuel Chinese listed non-real estate firms to improve innovation investments.

\section{Baseline results}

Column (1) in Table 3 reports the results of real estate investment motivations. Column (1) shows that the coefficient of the real estate investment of the non-real estate firms is significantly negative, which verifies that real estate investment really does crowd out the $R \& D$ investment in the non-real estate firms. A $1 \%$ increase in the real estate business income sees an average decrease in the R\&D investment of non-real estate firms of $1.25 \%$. Hence, there exists the investment motivation for real estate investment in non-real estate firms. Columns (2) and (3) report the expectation of the HPR on the real estate investment in non-real estate firms. The results show that the HPR duration has negative effects on the real estate investment in the non-real estate firms. Column (2) shows that a one standard deviation increase in the total years of the HPR implementation in the firmheadquarter city leads to $54.75 \%$ rebatements in the real estate income of a non-real estate firm. ${ }^{3}$ Similarly, Column (3) displays that a one standard deviation increase in the weighted total years of the HPR implementation in the firm headquarter and subsidiaries

${ }^{3}$ For comparison, we translate the coefficients of the HPR into economic significance by multiplying standard deviation (thereinafter). For instance, $-54.75 \%=\dot{\beta_{1}^{\prime}}=\beta_{1} \times \sigma_{H P R \_}=-0.7211 \times 0.7593$. 
Table 1 The definitions and metrics of majority variables

\begin{tabular}{|c|c|c|c|}
\hline \multicolumn{2}{|l|}{ Variable } & \multirow{2}{*}{$\begin{array}{l}\text { Definition } \\
R \& D \text { investment }\end{array}$} & \multirow{2}{*}{$\begin{array}{l}\text { Metrics } \\
\text { Logarithm value of R\&D investment }\end{array}$} \\
\hline $\begin{array}{l}\text { Dependent } \\
\text { variable }\end{array}$ & $R D$ & & \\
\hline \multirow[t]{2}{*}{$\begin{array}{l}\text { Independent } \\
\text { variable }\end{array}$} & $\begin{array}{l}H P R_{-} \\
S\end{array}$ & HPR duration & $\begin{array}{l}\text { Total years of HPR implementation in a city, in which headquarters } \\
\text { reside }\end{array}$ \\
\hline & $\begin{array}{l}H P R_{-} \\
W A\end{array}$ & $\begin{array}{l}\text { Weighted HPR } \\
\text { duration }\end{array}$ & $\begin{array}{l}\text { Total years of HPR implementation weighted by real estate income } \\
\text { proportions between headquarter and subsidiaries in different cities } \\
\text { and accelerated by the sum-of-the-years'-digits method }\end{array}$ \\
\hline $\begin{array}{l}\text { Mediator } \\
\text { variable }\end{array}$ & $R E$ & $\begin{array}{l}\text { Real estate } \\
\text { investment }\end{array}$ & Logarithm value of real estate income plus 1 \\
\hline \multirow{6}{*}{$\begin{array}{l}\text { Control } \\
\text { variable }\end{array}$} & Size & Firm size & Logarithm value of total assets \\
\hline & LEV & Debt ratio & Total debts to total assets ratio \\
\hline & Growth & Growth & Growth rate of sales income \\
\hline & $R O A$ & Return on asset & Net profits to total assets \\
\hline & Top5 & $\begin{array}{l}\text { Corporate } \\
\text { governance }\end{array}$ & Share ratio of top five shareholders \\
\hline & State & Firm nature & State-owned enterprise equals 1 , otherwise 0 \\
\hline
\end{tabular}

cities gives rise to a $45.14 \%$ reduction in the real estate income of the non-real estate firms. As a consequence, the expectation of the HPR significantly curtails the real estate investment of the non-real estate firms.

Table 4 reports the mediating mechanism. Columns (1) and (2) report the coefficients of HPR_S. Column (1) indicates that a one standard deviation increase in the total duration of the HPR implementation in the firm headquarter cities raises the R\&D investment in the listed non-real estate firms by $5.21 \%$. Column (2) shows that the coefficient of the real estate investment is negative, while the coefficient of the HPR duration is positive. A $1 \%$ increase in the real estate income of a non-real estate firm sees a decline in the ratio of R\&D investment of $0.97 \%$. A one standard deviation increase in the total duration of the HPR implementation in firm headquarter cities raises the ratio of $R \& D$ investment in the listed non-real estate firms by $4.67 \%$. Apparently, the coefficient of the HPR duration in Column (2) is less than that in Column (1). It proves that there exists a partial mediating effect of real estate investment on innovation investment in the non-real estate firms. Columns (3) and (4) of Table 4 report the coefficients of HPR - WA on the innovation investment in the non-real estate firms. Similarly, it also turns

Table 2 Summary statistics

\begin{tabular}{llllll}
\hline Variable & No. of obs. & Mean & Min. & Max. & S.D. \\
\hline RD & 11,786 & 17.3690 & 6.9078 & 23.6834 & 1.6401 \\
HPR_S & 11,786 & 0.1574 & 0.0000 & 7.0000 & 0.7593 \\
HPR_WA & 11,786 & 0.0335 & 0.0000 & 0.9722 & 0.1521 \\
RE & 11,786 & 0.8892 & 0.0000 & 27.3724 & 4.0551 \\
Size & 11,786 & 21.9192 & 17.4260 & 28.5087 & 1.2709 \\
LEV & 11,786 & 0.4055 & 0.0075 & 3.7059 & 0.2203 \\
Growth & 11,786 & 0.1699 & -0.9913 & 3.9429 & 0.3714 \\
ROA & 11,786 & 0.0473 & -0.9586 & 1.2016 & 0.0650 \\
Top5 & 11,786 & 0.5386 & 0.0298 & 0.9923 & 0.1533 \\
State & 11,786 & 0.3760 & 0.0000 & 1.0000 & 0.4844 \\
\hline
\end{tabular}




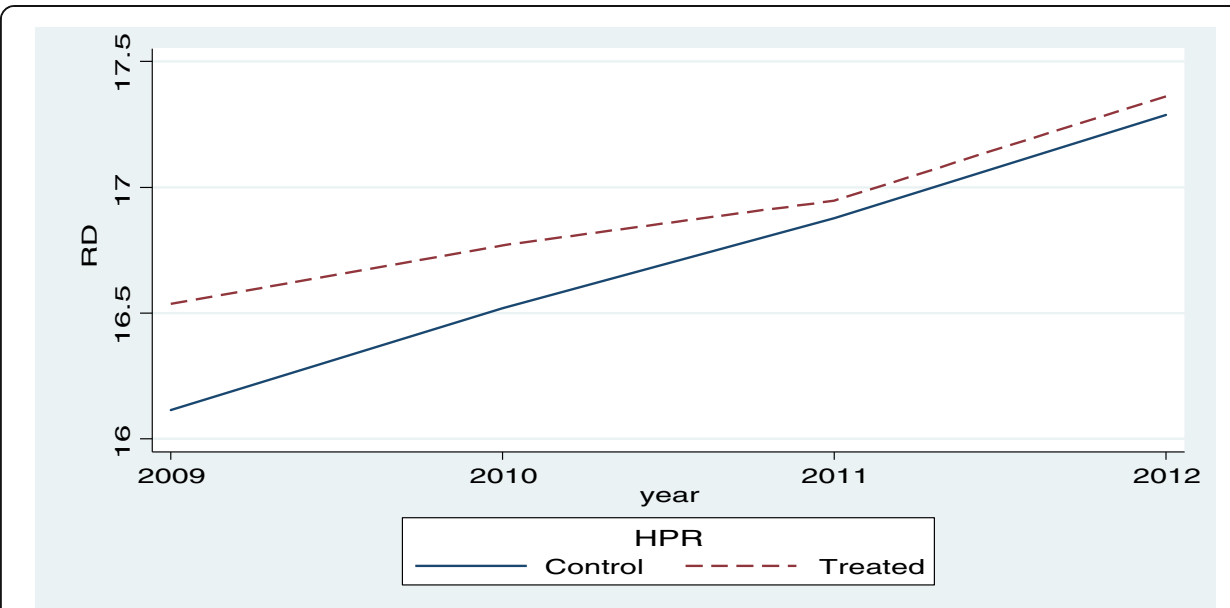

Fig. 1 The R\&D investment of Chinese listed non-real estate firms in cities with and without the HPR during the period 2009-2012

Table 3 The HPR, real estate investment, and corporate innovation

\begin{tabular}{|c|c|c|c|}
\hline \multirow[t]{2}{*}{ Variable } & (1) & $(2)$ & (3) \\
\hline & $Y=R D_{i t}$ & $Y=R E_{i t}$ & $Y=R E_{i t}$ \\
\hline \multirow[t]{2}{*}{$\overline{R E_{i t}}$} & $-0.0125^{* *}$ & & \\
\hline & $(-2.289)$ & & \\
\hline \multirow[t]{2}{*}{$H P R \_S_{i t}$} & & $-0.7211^{* * *}$ & \\
\hline & & $(-2.794)$ & \\
\hline \multirow[t]{2}{*}{$H P R_{-} W A_{i t}$} & & & $-2.9679^{* *}$ \\
\hline & & & $(-2.193)$ \\
\hline \multirow[t]{2}{*}{ Size $_{i t}$} & $0.6919 * * *$ & -0.0388 & -0.0289 \\
\hline & $(15.200)$ & $(-0.404)$ & $(-0.289)$ \\
\hline \multirow[t]{2}{*}{$L E V_{i t}$} & -0.1410 & $0.3487^{*}$ & $0.3804^{* *}$ \\
\hline & $(-0.957)$ & $(1.885)$ & (1.992) \\
\hline \multirow[t]{2}{*}{ Growth $_{i t}$} & 0.0174 & 0.0396 & 0.0521 \\
\hline & $(0.670)$ & $(0.614)$ & $(0.781)$ \\
\hline \multirow[t]{2}{*}{$R O A_{i t}$} & $0.6469^{* *}$ & 0.1091 & 0.0835 \\
\hline & $(2.431)$ & $(0.388)$ & $(0.291)$ \\
\hline \multirow[t]{2}{*}{ Top5 $5_{i t}$} & $0.6143^{* * *}$ & 0.0414 & -0.2289 \\
\hline & (3.544) & $(0.098)$ & $(-0.491)$ \\
\hline \multirow[t]{2}{*}{ State $_{i t}$} & $-0.2189^{*}$ & -0.0656 & -0.0475 \\
\hline & $(-1.897)$ & $(-0.370)$ & $(-0.289)$ \\
\hline \multirow[t]{2}{*}{ Constant } & 1.1684 & 3.7593 & 3.9461 \\
\hline & $(1.078)$ & $(1.592)$ & (1.619) \\
\hline Industry FE & YES & YES & YES \\
\hline Firm FE & YES & YES & YES \\
\hline Year FE & YES & YES & YES \\
\hline No. of obs. & 11,786 & 11,786 & 11,786 \\
\hline Number of firms & 1830 & 1830 & 1830 \\
\hline$R^{2}$ : within & 0.4642 & 0.0876 & 0.0717 \\
\hline
\end{tabular}

Notes. $* * * *$, and ${ }^{*}$ denote the significance levels at $1 \%, 5 \%$, and $10 \%$, respectively; parentheses are $t$ values (thereinafter) 
Table 4 The mediating effects of the HPR on corporate innovation

\begin{tabular}{|c|c|c|c|c|}
\hline \multirow[t]{2}{*}{ Variable } & \multirow{2}{*}{$\begin{array}{l}(1) \\
Y=R D_{i t}\end{array}$} & \multirow{2}{*}{$\begin{array}{l}(2) \\
Y=R D_{i t}\end{array}$} & \multirow{2}{*}{$\begin{array}{l}\text { (3) } \\
Y=R D_{i t}\end{array}$} & \multirow{2}{*}{$\begin{array}{l}(4) \\
Y=R D_{i t}\end{array}$} \\
\hline & & & & \\
\hline \multirow[t]{2}{*}{$\overline{H P R} \_S_{i t}$} & $0.0686^{* *}$ & $0.0615^{* *}$ & & \\
\hline & $(2.259)$ & $(2.027)$ & & \\
\hline \multirow[t]{2}{*}{ Difference in HPR_S Sit Coefficients } & \multicolumn{2}{|c|}{ Diff. $=0.0071$} & & \\
\hline & \multicolumn{2}{|c|}{ Chi-square $=3.01^{*}$} & & \\
\hline \multirow[t]{2}{*}{$H P R_{-} W A_{i t}$} & & & $0.3688^{* *}$ & $0.3370^{* *}$ \\
\hline & & & $(2.162)$ & $(1.984)$ \\
\hline \multirow[t]{2}{*}{ Difference in HPR_WA ${ }_{i t}$ Coefficients } & & & \multicolumn{2}{|c|}{ Diff. $=0.0318$} \\
\hline & & & \multicolumn{2}{|c|}{ Chi-square $=2.87^{*}$} \\
\hline \multirow[t]{2}{*}{$R E$} & & $-0.0097^{*}$ & & $-0.0107^{*}$ \\
\hline & & $(-1.705)$ & & $(-1.930)$ \\
\hline \multirow[t]{2}{*}{ Size $_{i t}$} & $0.6920^{* * *}$ & $0.6917^{* * *}$ & $0.6907^{* * *}$ & $0.6904^{* * *}$ \\
\hline & $(15.250)$ & $(15.250)$ & $(15.181)$ & $(15.191)$ \\
\hline \multirow[t]{2}{*}{$L E V_{i t}$} & -0.1376 & -0.1342 & -0.1388 & -0.1347 \\
\hline & $(-0.934)$ & $(-0.911)$ & $(-0.941)$ & $(-0.915)$ \\
\hline \multirow[t]{2}{*}{ Growth $_{i t}$} & 0.0182 & 0.0186 & 0.0171 & 0.0176 \\
\hline & $(0.701)$ & $(0.714)$ & $(0.658)$ & $(0.678)$ \\
\hline \multirow[t]{2}{*}{$R O A_{i t}$} & $0.6437^{* *}$ & $0.6448^{* *}$ & $0.6463^{* *}$ & $0.6472^{* *}$ \\
\hline & $(2.423)$ & $(2.427)$ & $(2.428)$ & $(2.431)$ \\
\hline \multirow[t]{2}{*}{ Top5 $5_{\text {it }}$} & $0.5845^{* * *}$ & $0.5849 * * *$ & $0.6077^{* * *}$ & $0.6053^{* * *}$ \\
\hline & $(3.350)$ & (3.354) & $(3.501)$ & $(3.491)$ \\
\hline \multirow[t]{2}{*}{ State $_{i t}$} & $-0.2143^{*}$ & $-0.2150^{*}$ & $-0.2153^{*}$ & $-0.2158^{*}$ \\
\hline & $(-1.851)$ & $(-1.857)$ & $(-1.862)$ & $(-1.866)$ \\
\hline \multirow[t]{2}{*}{ Constant } & 1.1977 & 1.2342 & 1.2015 & 1.2438 \\
\hline & $(1.109)$ & $(1.143)$ & $(1.110)$ & (1.149) \\
\hline Industry FE & YES & YES & YES & YES \\
\hline Firm FE & YES & YES & YES & YES \\
\hline Year FE & YES & YES & YES & YES \\
\hline No. of obs. & 11,786 & 11,786 & 11,786 & 11,786 \\
\hline Number of firms & 1830 & 1830 & 1830 & 1830 \\
\hline$R^{2}$ : within & 0.4646 & 0.4648 & 0.4644 & 0.4647 \\
\hline
\end{tabular}

Notes. ${ }^{* *},{ }^{* *}$, and ${ }^{*}$ denote the significance levels at $1 \%, 5 \%$, and $10 \%$, respectively; parentheses are $t$

values (thereinafter)

out that the alternative HPR duration measure significantly advances innovation investment and real estate investment and plays a mediator role in corporate innovation. More specifically, Column (4) exhibits that a $1 \%$ increase in the real estate income of a listed non-real estate firm leads to a fall in the R\&D investment of $1.07 \%$. A one standard deviation increase in the weighted total years of the HPR implementation in the firm headquarter and subsidiaries cities raises the R\&D investment by $5.13 \%$, which is less than the coefficients in Column (3). Hence, the HPR not only affects the housing market but also has positive spillover effects and externalities on the innovation investment. Since the difference between $t$-statistics of the HPR coefficients is not much, we further implement the $t$-value tests to decide the partial mediating effect of real estate investment on corporate innovation. As shown in Table 4, the difference of the HPR 
coefficients is significant at the $10 \%$ significance level, which further verifies the partial mediating effect of real estate investment on corporate innovation.

To further examine the lagged effects of the HPR on real estate investment and innovation investment, Table 5 shows that the HPR has no effects on the real estate investment and $R \& D$ investment in the non-real estate firms at the first policy implementation year. Starting from the second policy implementation year, the HPR has significantly lagged effects on the real estate investment and innovation investment in the non-real estate firms. More specifically, the lagged effects accrue to the crust from the second policy implementation year to the third policy implementation year on both the real estate investment and the R\&D investment. In terms of real estate investment in the non-real estate firms, the absolute values of HPR implementation rise from about 2.01 at the second policy implementation year to 3.98 at the third policy implementation year. In terms of corporate innovation, the absolute values of HPR policy implementation rise from 0.39 in the second implementation year to 0.47 at the third implementation year. From the fourth policy implementation year, the coefficients of HPR policy implementation decrease and are stable onwards. This implies that the expectation of HPR policy implementation is first reinforced and then steady over time. Hence, the lagged effects of HPR policy implementation further prove that the longer duration of HPR policy implementation is favorable to corporate innovation.

\section{Robustness tests}

In the above sectors, this research investigates the effects of the HPR on the volume of $R \& D$ investment in non-real estate firms. However, modeling whether a firm engages in R\&D investment or not is also vital. As such, we first apply the Probit models to explore if the HPR affects a firm's R\&D investment decisions.

$$
\begin{gathered}
\operatorname{Pr}\left(R D_{i t}^{d}\right)=\chi_{0}+\chi_{1} \text { HPR }_{i t}+\chi_{2} \text { RE }_{i t}+\chi_{3} \text { Size }_{i t}+\chi_{4} \text { LEV }_{i t}+\chi_{5} \text { Growth }_{i t}+\chi_{6} \text { ROA }_{i t}+\chi_{7} \text { Top }_{i t} \\
+\chi_{8} \text { State }_{i t}+\chi_{9} \text { Industry }_{i t}+\chi_{10} \text { Firm }_{i}+\chi_{11} \text { Year }_{t}+\pi_{i t}
\end{gathered}
$$

In Model (7), $R D_{i t}^{d}$ is a dummy variable with the value of 1 if a firm conducts $R \& D$ investment and 0 otherwise, $H P R_{i t}^{d}$ is a dummy variable with the value of 1 if an HPR policy is implemented and 0 otherwise. Table 6 shows that the HPR significantly increases the likelihood of R\&D investment decisions in non-real estate firms, while real estate investment significantly decreases the likelihood of R\&D investment decisions in nonreal estate firms. It is evident that the baseline results of how much a firm conducts $R \& D$ investment are robust.

Second, to further examine the heterogeneous responses of corporate R\&D investment to housing policies across industries, we analyze the effects of the HPR on R\&D investment in high-tech industry and non-high-tech industry, respectively. According to the classification of high technology industry issued by the National Bureau of Statistics, we classify the listed firms into high-tech industries and non-high-tech industries. Table 7 shows that the HPR has significant impacts on the R\&D investment of the listed firms in non-high-tech industries, but no significant impacts in high-tech industries. That is, the R\&D investment of listed firms in non-high-tech industries shows a 
Table $\mathbf{5}$ The lagged effects of HPR policy implementation on corporate innovation

\begin{tabular}{|c|c|c|}
\hline \multirow[t]{2}{*}{ Variable } & (1) & (2) \\
\hline & $Y=R E_{i t}$ & $Y=R D_{i t}$ \\
\hline \multirow[t]{2}{*}{$H P R S_{-} S_{1 j t}$} & -0.9184 & 0.1408 \\
\hline & $(-1.056)$ & $(1.151)$ \\
\hline \multirow[t]{2}{*}{$H P R \_S_{2 j t}$} & $-2.0081^{* *}$ & $0.3882^{* * *}$ \\
\hline & $(-1.963)$ & $(2.586)$ \\
\hline \multirow[t]{2}{*}{$H P R_{-} S_{3 j t}$} & $-3.9815^{* * *}$ & $0.4705^{* * *}$ \\
\hline & $(-3.552)$ & (3.120) \\
\hline \multirow[t]{2}{*}{$H P R S_{-} S_{\text {ijt }}$} & $-3.3672^{* *}$ & $0.3564^{* *}$ \\
\hline & $(-2.392)$ & $(2.246)$ \\
\hline \multirow[t]{2}{*}{$H P R \_S_{5 j t}$} & $-3.7494^{* *}$ & $0.3239^{*}$ \\
\hline & $(-2.479)$ & $(1.851)$ \\
\hline \multirow[t]{2}{*}{$H P R \_S_{6 j t}$} & $-3.3185^{* *}$ & $0.3682^{* *}$ \\
\hline & $(-2.176)$ & $(2.028)$ \\
\hline \multirow[t]{2}{*}{$H P R \_S_{7 y t}$} & $-3.1270^{* *}$ & $0.4568^{*}$ \\
\hline & $(-2.147)$ & $(1.854)$ \\
\hline \multirow[t]{2}{*}{ Size $_{i t}$} & -0.0319 & $0.6909^{* * *}$ \\
\hline & $(-0.340)$ & $(15.227)$ \\
\hline \multirow[t]{2}{*}{$L E V_{i t}$} & $0.3309^{*}$ & -0.1341 \\
\hline & $(1.811)$ & $(-0.910)$ \\
\hline \multirow[t]{2}{*}{ Growth $_{i t}$} & 0.0473 & 0.0166 \\
\hline & $(0.758)$ & (0.639) \\
\hline \multirow[t]{2}{*}{$R O A_{i t}$} & 0.1587 & $0.6390^{* *}$ \\
\hline & $(0.579)$ & $(2.405)$ \\
\hline \multirow[t]{2}{*}{ Top5 $5_{i t}$} & -0.0088 & $0.5950^{* * *}$ \\
\hline & $(-0.021)$ & (3.412) \\
\hline \multirow[t]{2}{*}{ State $_{i t}$} & -0.0285 & $-0.2197^{*}$ \\
\hline & $(-0.179)$ & $(-1.898)$ \\
\hline \multirow[t]{2}{*}{ Constant } & 3.4641 & 1.2472 \\
\hline & $(1.511)$ & $(1.155)$ \\
\hline Industry FE & YES & YES \\
\hline Firm FE & YES & YES \\
\hline Year FE & YES & YES \\
\hline No. of obs. & 11,786 & 11,786 \\
\hline Number of firms & 1830 & 1830 \\
\hline$R^{2}$ : within & 0.1029 & 0.4654 \\
\hline
\end{tabular}

Notes. ${ }^{* *},{ }^{* *}$, and ${ }^{*}$ denote the significance levels at $1 \%, 5 \%$, and $10 \%$, respectively; parentheses are $t$

values (thereinafter)

stronger response than that in high-tech industries. In essence, the firms in non-hightech industries are more speculative than those in high-tech industries.

Third, the enforcement of the HPR is not random and a selection bias problem exists. The cities, whether or not they are implementing the HPR, have distinct disparities in urban house prices, population density, and disposable income per capita. Thereby, there is an estimation error in the DID model, in which the samples of corporate headquarter cities with the HPR are classified as the treatment group, and the others 
Table 6 The effect of the HPR on whether a firm conducts R\&D investment

\begin{tabular}{|c|c|}
\hline Variable & $Y=R D_{i t}^{d}$ \\
\hline \multirow[t]{2}{*}{$\overline{H P R_{i t}^{d}}$} & $0.2574^{* * *}$ \\
\hline & $(7.061)$ \\
\hline \multirow[t]{2}{*}{$R E_{i t}$} & $-0.0319^{* * *}$ \\
\hline & $(-11.396)$ \\
\hline \multirow[t]{2}{*}{ Size $_{i t}$} & $0.1747^{* * *}$ \\
\hline & (11.399) \\
\hline \multirow[t]{2}{*}{$L E V_{i t}$} & $-0.7129^{* * *}$ \\
\hline & $(-8.263)$ \\
\hline \multirow[t]{2}{*}{ Growth $_{i t}$} & $0.0765^{*}$ \\
\hline & $(1.752)$ \\
\hline \multirow[t]{2}{*}{$R O A_{i t}$} & -0.0363 \\
\hline & $(-0.169)$ \\
\hline \multirow[t]{2}{*}{ Top5 $5_{\text {it }}$} & $0.8972^{* * *}$ \\
\hline & (8.788) \\
\hline \multirow[t]{2}{*}{ State $_{i t}$} & $-0.1029^{* * *}$ \\
\hline & $(-3.077)$ \\
\hline \multirow[t]{2}{*}{ Constant } & $-4.6123^{* * *}$ \\
\hline & $(-13.243)$ \\
\hline Industry FE & YES \\
\hline Year FE & YES \\
\hline No. of obs. & 14,992 \\
\hline Number of firms & 2156 \\
\hline Pseudo $R^{2}$ & 0.3924 \\
\hline
\end{tabular}

Notes. ${ }^{* *},{ }^{* *}$, and ${ }^{*}$ denote the significance levels at $1 \%, 5 \%$, and $10 \%$, respectively; parentheses are $t$ values (thereinafter)

without the HPR serve as the control group. As such, this research first uses the PSM approach to identify the treatment group and the control group, then takes a DID approach to estimate the peer-matched samples. According to the study by Deng et al. (2014), this research employs the city-level and firm-level variants to estimate the likelihood of the HPR. The Probit model can be written as follows.

$$
\operatorname{Pr}\left(\text { Treat }_{i t}\right)=\phi_{0}+\phi_{1} X_{j t-1}+\phi_{2} Z_{i t}+\theta_{i t}
$$

In Model (8), Treat ${ }_{i t}$ denotes the dummy variables of the treatment group with the HPR in reference to the control group without the HPR, $X_{j t-1}$ contains the lagged citylevel factors, such as housing price (HP), population density (PD), disposable income per capita (Inc), ${ }^{4}$ and $Z_{i t}$ contains the firm-level factors, such as firm size (Size), debt ratio ( $L E V$ ), growth (Growth), asset return $(R O A)$, corporate governance (Top5), and firm nature (State). It is noteworthy that a couple of cities experienced implementing, canceling, and re-implementing the HPR. On the one hand, the HPR have lagged effects, in that the first-time HPR impact the second-time HPR. On the other hand, as the four first-tier cities of Beijing, Shanghai, Shenzhen, and Guangzhou, are not likely to

${ }^{4} H P, P D$ and $I n c$ are the logarithm values of urban housing prices, urban population density and urban disposable income per capita in a city where the corporate headquarters reside. 
Table 7 The effects of the HPR on corporate R\&D investments across industries

\begin{tabular}{|c|c|c|c|c|}
\hline \multirow[t]{2}{*}{ Variable } & $\begin{array}{l}\text { High-tech } \\
\text { industries }\end{array}$ & $\begin{array}{l}\text { Non-high-tech } \\
\text { industries }\end{array}$ & $\begin{array}{l}\text { High-tech } \\
\text { industries }\end{array}$ & $\begin{array}{l}\text { Non-high-tech } \\
\text { industries }\end{array}$ \\
\hline & $Y=R D_{i t}$ & $Y=R D_{i t}$ & $Y=R D_{i t}$ & $Y=R D_{i t}$ \\
\hline \multirow[t]{2}{*}{$H P R_{-} S_{i t}$} & 0.0730 & $0.0598^{*}$ & & \\
\hline & $(0.997)$ & $(1.857)$ & & \\
\hline \multirow[t]{2}{*}{$H P R_{-} W A_{i t}$} & & & 0.2982 & $0.3339^{*}$ \\
\hline & & & (0.688) & (1.848) \\
\hline \multirow{2}{*}{ Size $_{i t}$} & $0.5207^{* * *}$ & $0.6896^{* * *}$ & $0.5198^{* * *}$ & $0.6886^{* * *}$ \\
\hline & $(6.173)$ & (12.895) & $(6.164)$ & (12.842) \\
\hline \multirow[t]{2}{*}{$L E V_{i t}$} & $0.4349^{* *}$ & -0.1813 & $0.4230^{* *}$ & -0.1806 \\
\hline & $(2.474)$ & $(-1.086)$ & (2.389) & $(-1.082)$ \\
\hline \multirow[t]{2}{*}{ Growth $_{i t}$} & $0.0968^{* *}$ & 0.0072 & $0.0951^{* *}$ & 0.0062 \\
\hline & $(2.045)$ & $(0.231)$ & $(2.002)$ & $(0.201)$ \\
\hline \multirow[t]{2}{*}{$R O A_{i t}$} & $0.4914^{*}$ & $0.6070^{*}$ & $0.5012^{*}$ & $0.6090^{*}$ \\
\hline & (1.899) & $(1.916)$ & (1.948) & (1.918) \\
\hline \multirow[t]{2}{*}{ Top5 $5_{i t}$} & 0.4215 & $0.4837^{* *}$ & 0.4342 & $0.5054^{* *}$ \\
\hline & $(1.327)$ & $(2.433)$ & $(1.367)$ & $(2.554)$ \\
\hline \multirow[t]{2}{*}{ State $_{i t}$} & $0.2475^{* *}$ & $-0.3025^{* *}$ & $0.2458^{* *}$ & $-0.3035^{* *}$ \\
\hline & $(2.187)$ & $(-2.104)$ & $(2.173)$ & $(-2.113)$ \\
\hline \multirow[t]{2}{*}{ Constant } & $5.0063^{* * *}$ & 1.2524 & $5.0623^{* * *}$ & 1.2491 \\
\hline & $(2.673)$ & (1.019) & $(2.711)$ & $(1.013)$ \\
\hline Industry FE & YES & YES & YES & YES \\
\hline Firm FE & YES & YES & YES & YES \\
\hline Year FE & YES & YES & YES & YES \\
\hline No. of obs. & 2358 & 9428 & 2358 & 9428 \\
\hline $\begin{array}{l}\text { Number of } \\
\text { firms }\end{array}$ & 465 & 1613 & 465 & 1613 \\
\hline$R^{2}$ :within & 0.5708 & 0.4339 & 0.5706 & 0.4339 \\
\hline
\end{tabular}

Notes. ${ }^{* *},{ }^{* *}$, and ${ }^{*}$ denote the significance levels at $1 \%, 5 \%$, and $10 \%$, respectively; parentheses are $t$ values (thereinafter)

appropriately conduct peer matching, the samples in the four cities are removed from the treatment group. As such, this research merely examines the before and after twoyear effects of the first-time HPR policy implementation on corporate innovation from 2009 to 2012. In terms of the estimated results of Model (8), this research adopts the nearest matching approach to match three control groups for one treatment group. Similarly, the cancellation of the HPR in different cities is not random. This research also employs the PSM method to match samples between the treatment group and the control group and then applies a DID model to estimate the effects of HPR policy cancellation. In this case, the dummy variables of the treatment group in Model (8) have changed to stand for whether the cities in which the firm headquarters reside cancel the HPR. Our sample shows that there are 39 cities out of 43 cities with the HPR that was canceled in 2015. We take these 39 cities as the treatment group and the others serve as the control group. Thus, the subsample vintage is automatically confined from 2013 to 2016.

Next, this research applies a DID model to estimate the effects of the HPR on corporate innovation. The DID model is expressed as follows. 


$$
\begin{aligned}
& R D_{i t}=\kappa_{0}+\kappa_{1} \text { Treat }_{i t} \times \text { After }_{i t}+\kappa_{2} \text { Size }_{i t}+\kappa_{3} L E V_{i t}+\kappa_{4} \text { Growth }_{i t}+\kappa_{5} R O A_{i t}+\kappa_{6} \text { Top }_{i t} \\
& +\kappa_{7} \text { State }_{i t}+\kappa_{8} \text { Industry }_{i t}+\kappa_{9} \text { Year }_{t}+\delta_{i t} 5 p c
\end{aligned}
$$

In Model (9), After ${ }_{i t}$ is a dummy variable for whether the HPR is implemented or canceled, and has the value of 1 if the HPR is implemented and 0 if canceled. In theory, if the HPR policy is implemented, $\kappa_{1}$ is expected to be positive, which predicts that the implementation of an HPR is favorable for corporate innovation. By contrast, if the HPR is canceled, $\kappa_{1}$ is supposed to be negative, which anticipates that the cancellation of an HPR has a negative externality on corporate innovation.

Columns (1) and (2) in Table 8 report the DID estimated results. Column (1) shows that the implementation of HPR has great positive externalities on the ratios of R\&D investment in the non-real estate firms. Relative to non-real estate firms in the cities without the HPR, the ratios of R\&D investment in the non-real estate firms in the cities with the HPR increase by $30.31 \%$ on average. Column (2) illustrates that the cancellation of the HPR has great negative externalities on the ratios of R\&D investment in the non-real estate firms. Relative to the non-real estate firms in the cities without the cancellation of HPR, the ratios of R\&D investments in the non-real estate

Table 8 The PSM-DID estimated results of the implementation and cancellation of the HPR on

\begin{tabular}{|c|c|c|}
\hline \multirow[t]{2}{*}{ Variable } & (1) & (2) \\
\hline & $Y=R D_{i t}$ & $Y=R D_{i t}$ \\
\hline \multirow[t]{2}{*}{ Treat $_{i t} \times$ After $_{i t}$} & $0.3031^{* *}$ & $-0.2999^{* *}$ \\
\hline & $(2.094)$ & $(-2.028)$ \\
\hline \multirow[t]{2}{*}{ Size $_{i t}$} & $0.5862^{* * *}$ & $0.9295^{* * *}$ \\
\hline & (3.663) & $(14.082)$ \\
\hline \multirow[t]{2}{*}{$L E V_{i t}$} & 0.1771 & $-1.9966^{* * *}$ \\
\hline & $(0.557)$ & $(-5.972)$ \\
\hline \multirow[t]{2}{*}{ Growth $_{i t}$} & -0.0158 & 0.1459 \\
\hline & $(-0.215)$ & $(1.157)$ \\
\hline \multirow[t]{2}{*}{$R O A_{i t}$} & 0.4887 & -0.3722 \\
\hline & $(0.904)$ & $(-0.396)$ \\
\hline \multirow[t]{2}{*}{ Top5 $5_{\text {it }}$} & $2.2205^{* *}$ & -0.0759 \\
\hline & $(2.272)$ & $(-0.200)$ \\
\hline \multirow[t]{2}{*}{ State $_{i t}$} & -0.8092 & $-0.2024^{*}$ \\
\hline & $(-1.615)$ & $(-1.688)$ \\
\hline \multirow[t]{2}{*}{ Constant } & 3.7024 & -1.7939 \\
\hline & $(1.075)$ & $(-1.280)$ \\
\hline Industry FE & YES & YES \\
\hline Year FE & YES & YES \\
\hline No. of obs. & 1975 & 591 \\
\hline Number of firms & 918 & 310 \\
\hline$R^{2}$ & 0.261 & 0.624 \\
\hline
\end{tabular}
corporate innovation

Notes. ${ }^{* *},{ }^{* *}$, and ${ }^{*}$ denote the significance levels at $1 \%, 5 \%$, and $10 \%$, respectively; parentheses are $t$ values (thereinafter) 
firms in the cities with the cancellation of HPR declined by an average of $29.99 \%$. Hence, the cancellation of HPR is not beneficial for corporate innovation investment.

Lastly, although this research has applied the PSM-DID approach to resolve the selective bias and endogeneity problems between the HPR and corporate innovation, the endogeneity problem may also exist, due to the simultaneity problem and the omitted covariants (Yu and Zhang 2017). That is, corporate innovation might facilitate the increase in employees' income and housing demand, thereby escalating house prices and the possibility of HPR policy implementation. To tackle the endogeneity problem, this research takes the residential land area as an instrument of the HPR. In fact, land supply elasticity is highly correlated with house prices but uncorrelated with corporate innovation. According to the computation method of unweighted and weighted HPR durations, this research constructs the unweighted and weighted residential land area of RES_S and RES_WA, respectively. Table 9 reports the 2SLS results of HPR duration on corporate innovation. Columns (1) and (3) show that the unweighted and weighted residential land areas are negatively correlated with HPR durations, which corroborates that the instrumental variables are valid. Columns (2) and (4) show that the various instrumental variables of HPR duration not only positively affect the ratios of R\&D investments in non-real estate firms, but also have greater magnitudes than those in Table 4. These results further document that the baseline results are robust.

\section{Conclusions and policy implications}

Over the last two decades, real estate involvement has become pervasive in non-real estate firms due to the rocket-soaring house prices in China. The big concern for policymakers is that the real estate investment of non-real estate firms could impede corporate innovation and overall economic growth in the long run. On the other hand, the HPR serves as a key vehicle for cooling down the housing demand and house prices in some cities in China. Nevertheless, the expectation and externality of the HPR have not been well addressed in the previous literature. This research exploits whether the implementation and cancellation of the HPR affect the real estate investment and the corporate innovation in the listed non-real estate firms. This research employs a dataset of non-real estate listed firms in China's Shanghai and Shenzhen stock exchange markets during the period 2009-2016 and merges the HPR to the related cities where the corporate headquarter and subsidiaries reside. The empirical results reveal that the real estate investment in the listed non-real estate firms is starkly driven by the investment motivation. The real estate investment in listed non-real estate firms indeed crowds out the R\&D investment and hurts corporate innovation. The implementation of the HPR can dampen real estate investment and further advance $R \& D$ investment in listed nonreal estate firms. In particular, the HPR significantly encourages R\&D investment in non-high-tech firms. The real estate investment in non-real estate firms serves as a mediator between the HPR and corporate innovation investment. In contrast, if the HPR policies are canceled, the real estate investment rebounds and the innovation investment decreases in the non-real estate firms. Importantly, the expectation of the HPR has greater effects on corporate innovation investment. The HPR has lagged and overlapping effects in the second and third implementation years and becomes steady later. Taking the endogeneity problem and selection bias into account, the baseline results are also robust. 
Table 9 The 2SLS results of HPR duration on corporate innovation

\begin{tabular}{|c|c|c|c|c|}
\hline \multirow[t]{2}{*}{ Variable } & (1) & (2) & (3) & (4) \\
\hline & $Y=H P R_{-} S_{i t}$ & $Y=R D_{i t}$ & $\mathrm{Y}=H P R_{-} W A_{i t}$ & $Y=R D_{i t}$ \\
\hline \multirow[t]{2}{*}{$R E S_{\text {_ }} S_{\text {it }}$} & $-0.3928^{* * *}$ & & & \\
\hline & $(-5.67)$ & & & \\
\hline \multirow[t]{2}{*}{$H P R_{-} S_{i t}$} & & $0.8480^{* * *}$ & & \\
\hline & & $(2.634)$ & & \\
\hline \multirow[t]{2}{*}{$R E S_{-} W A_{i t}$} & & & $-0.0601^{* * *}$ & \\
\hline & & & $(-5.14)$ & \\
\hline \multirow[t]{2}{*}{$H P R \_W A_{i t}$} & & & & $5.3907^{* *}$ \\
\hline & & & & $(2.537)$ \\
\hline \multirow[t]{2}{*}{ Size $_{i t}$} & 0.0020 & $0.6926^{* * *}$ & $0.0044^{*}$ & $0.6707^{* * *}$ \\
\hline & $(0.14)$ & $(17.781)$ & $(1.82)$ & $(16.471)$ \\
\hline \multirow[t]{2}{*}{$L E V_{i t}$} & $-0.1406^{* * *}$ & -0.0161 & $-0.0224^{*}$ & -0.0138 \\
\hline & $(-2.77)$ & $(-0.120)$ & $(-1.84)$ & $(-0.097)$ \\
\hline \multirow[t]{2}{*}{ Growth $_{i t}$} & $-0.0218^{*}$ & 0.0301 & -0.0010 & 0.0170 \\
\hline & $(-1.76)$ & $(1.126)$ & $(-0.46)$ & $(0.632)$ \\
\hline$R O A_{i t}$ & 0.0340 & $0.6201^{* * *}$ & -0.0011 & $0.6546^{* * *}$ \\
\hline \multirow[t]{2}{*}{ Top5 $5_{\text {it }}$} & $(0.38)$ & $(2.603)$ & $(-0.06)$ & $(2.631)$ \\
\hline & $0.4800^{* * *}$ & 0.1988 & $0.0262^{* *}$ & $0.4654^{* * *}$ \\
\hline \multirow[t]{3}{*}{ State $_{i t}$} & $(6.34)$ & $(0.960)$ & $(2.14)$ & (3.028) \\
\hline & -0.0648 & -0.1627 & -0.0095 & -0.1662 \\
\hline & $(-1.30)$ & $(-1.504)$ & $(-1.49)$ & $(-1.579)$ \\
\hline \multirow[t]{2}{*}{$\mathrm{HP}_{i t}$} & $0.1024^{* *}$ & -0.0946 & $0.0145^{* *}$ & -0.0856 \\
\hline & $(2.22)$ & $(-1.008)$ & (2.19) & $(-0.916)$ \\
\hline \multirow[t]{2}{*}{$P D_{i t}$} & $0.1593^{* * *}$ & $-0.3504^{* * *}$ & $0.0156^{* *}$ & $-0.2981^{* *}$ \\
\hline & (3.39) & $(-2.589)$ & $(2.03)$ & $(-2.376)$ \\
\hline \multirow[t]{2}{*}{$\ln c_{i t}$} & $-0.0854^{* *}$ & $0.3104^{* *}$ & $-0.0176^{* *}$ & $0.3327^{* *}$ \\
\hline & $(-2.04)$ & $(2.104)$ & $(-2.12)$ & $(2.068)$ \\
\hline Industry FE & YES & YES & YES & YES \\
\hline Firm FE & YES & YES & YES & YES \\
\hline Year FE & YES & YES & YES & YES \\
\hline No. of obs. & 11,657 & 11,657 & 11,657 & 11,657 \\
\hline Number of firms & 1779 & 1779 & 1779 & 1779 \\
\hline Under identification test & 33.12 & & 26.75 & \\
\hline$P$-value & 8.67e-09 & & $2.32 \mathrm{e}-07$ & \\
\hline Weak identification test & 32.20 & & 26.37 & \\
\hline$R^{2}$ & & 0.3672 & & 0.3466 \\
\hline
\end{tabular}

Notes. ${ }^{* *}, * *$, and ${ }^{*}$ denote the significance levels at $1 \%, 5 \%$, and $10 \%$, respectively; parentheses are $t$ values (thereinafter)

This research has strong policy implications. On the one hand, the real estate investment in non-real estate firms is motivated by housing speculation, which will impede the corporate innovation in those firms. Hence, in order to encourage corporate innovation, it is necessary to implement the HPR to thwart the real estate investment in non-real estate firms, while it might be not appropriate to cancel the HPR. On the other hand, since the expectation of the HPR on corporate innovation is reinforced and then remains steady over time, 
policymakers should extend the implementation duration of the HPR where possible to shape the rational and steady expectations of housing market participants on the HPR. As the HPR has distinct spillover effects and positive externality on corporate innovation, policymakers should allow the HPR to serve as a long-term vehicle to improve corporate innovation in addition to regulating speculative demand for housing.

\section{Abbreviations}

R\&D: Research and development; GDP: Gross domestic product; HPR: Home purchase restriction; 2SLS: Two-stage least squares; PSM-DID: Propensity score matching and difference-in-differences; DID: Difference in differences; PSM: Propensity score matching

\section{Acknowledgements}

The authors are indebted to the discussants in the Global Chinese Real Estate Congress in 2019 and the workshop in real estate and corporate finance at the business school, Renmin University of China

\section{Authors' contributions}

We declare that all the authors have the equal contribution in this paper, while Changyu Chen is the corresponding author. All authors read and approved the final manuscript.

\section{Funding}

This research is funded by National Natural Science Foundation of China (Grant No.71373276).

\section{Availability of data and materials}

The firm-level data in this research are from CSMAR and Wind databases, while the city-level data are gathered from China Urban Construction Statistical Yearbooks. The implementation and cancellation of the HPR pertaining to the sample cities are collected from local government websites and the relevant official documents.

\section{Competing interests}

The authors declare that they have no competing interests.

\section{Author details}

${ }^{1}$ Department of Finance, Business School, Renmin University of China, 59 Zhongguancun Street, Haidian District, Beijing 100872, China. ${ }^{2}$ Department of Corporate Finance, School of Business, Hunan University, No.11 Lushan South Road, Yuelu District, Changsha 400082, China.

Received: 19 February 2020 Accepted: 18 September 2020

Published online: 12 November 2020

\section{References}

Barro, R. J. (1991). Economic growth in a cross section of countries. The Quarterly Journal of Economics, 106(2), 407-443.

Benhabib, J., \& Spiegel, M. M. (1994). The role of human capital in economic development evidence from aggregate crosscountry data. Journal of Monetary Economics, 34(2), 143-173.

Bernanke, B. S. (2013). The Federal Reserve and the financial crisis. Princeton: Princeton University Press.

Burnside, C., Eichenbaum, M., \& Rebelo, S. (2016). Understanding booms and busts in housing markets. Journal of Political Economy, 124(4), 1088-1147.

Campbell, J. R., Evans, C. L., Fisher, J. D., Justiniano, A., Calomiris, C. W., \& Woodford, M. (2012). Macroeconomic effects of Federal Reserve forward guidance. In Brookings papers on economic activity, (pp. 1-80).

Cao, J., Goh, J., Jiang, F., \& Yu, Y. (2014). Corporate real estate collateral and innovation. Asian Finance Association (AsianFA) 2014 conference paper.

Cao, J., Huang, B., \& Lai, R. (2015). On the effectiveness of housing purchase restriction policy in China: a difference in difference approach. In Research collection Lee Kong Chian School of Business, (pp. 1-46).

Chaney, T., Sraer, D., \& Thesmar, D. (2012). The collateral channel: how real estate shocks affect corporate investment. American Economic Review, 102(6), 2381-2409.

Chen, J., \& Wang, S. (2013). Thinking of China's economic de-"real-estate" under the background of industrial upgrading. Macroeconomics, 10, 125-129.

Chen, T., Liu, L., Xiong, W., \& Zhou, L. (2016). The speculation channel and crowding out channel: real estate shocks and corporate investment in China. Beijing: Peking University Working Paper.

Deng, B., Li, Z., \& Zhang, H. (2014). Does the house purchase quota policy have the regulation effect on housing prices? Statistical Research, 31(11), 50-57.

Du, Z., \& Zhang, L. (2015). Home-purchase restriction, property tax and housing price in China: a counterfactual analysis. Journal of Econometrics, 188(2), 558-568.

Gan, J. (2007). Collateral, debt capacity, and corporate investment: evidence from a natural experiment. Journal of Financial Economics, 85(3), 709-734.

Han, L., \& Zhao, H. (2011). The nonlinear relationship of speculative demand, rigid demand and real estate prices rise: based on the empirical study of spatial econometrics model. Journal of Industrial Technological Economics, 30(10), 119-125.

Hu, N., Wang, X., Sun, L., \& Jin, Q. (2019). Can the housing purchase restriction policy promote the enterprises to "shift from the fictitious economy to the real economy"? A research based on the DID design. Nankai Business Review, 22(4), 20-31.

Krugman, P. R. (1998). It's back: Japan's slump and the return of the liquidity trap. Brookings Papers on Economic Activity, 29(2), $137-206$. 
Kuang, W. (2010). Expectation, speculation and urban housing price volatility in China. Economic Research Journal, 45(9), 6879.

Kuang, W., Li, T., \& Xiao, J. (2020). Housing prices and household savings: evidence from urban China. Economic and Political Studies, 8(1), 96-114.

Liu, J. D., \& Guan, X. H. (2019). Does VAT deduction drive enterprises from real to virtual? From the perspective of investment structure. Journal of Finance and Economics, 45(11), 112-124.

Liu, J., Zhang, B., \& Huang, Z. (2012). Purchase restriction policy and the dynamic change of house price. Economic Perspectives, 3, 49-56.

Liu, L. (2008). Does overseas "hot-money" inflow drives the house price or stock market rise? Evidence from the Chinese market. Journal of Financial Research, 10, 52-74.

Luo, Z., \& Zhang, C. (2015). Credit expansion, real estate investment and the efficiency of resource allocation in industry. Journal of Financial Research, 421(7), 64-79.

Mao, Y. (2017). Managing innovation: the role of collateral. In Kelley School of Business Research Paper, (pp. 17-25).

Meng, Q., Gong, X., \& Lin, K. (2018). Does "the restriction of real estate investment" facilitate technology innovation? Evidence from a quasi-natural experiment of central state-owned enterprises. Journal of Finance and Economics, 44(9), 96-109.

Miao, J., \& Wang, P. (2014). Sectoral bubbles, misallocation, and endogenous growth. Journal of Mathematical Economics, 53, 153-163.

Morris, S., \& Shin, H. S. (2002). Social value of public information. American Economic Review, 92(5), 1521-1534.

Morris, S., \& Shin, H. S. (2008). Coordinating expectations in monetary policy. In Central Banks as Economic Institutions, (pp. 88-104).

Quan, X. F., \& Yin, H. Y. (2017). Chinese short selling mechanism and corporate innovation: a natural experiment from Chinese margin trading program. Management World, (1), 128-144.

Rong, Z., \& Wang, W. (2014). Housing boom and firm's entry to real estate: evidence from listed non-real estate firms in China. Journal of Financial Research, 406(4), 162-177.

Rong, Z., Wang, W., \& Gong, Q. (2016). Housing price appreciation, investment opportunity, and firm innovation: evidence from China. Journal of Housing Economics, 33, 34-58.

Ruiz, I., \& Vargas-Silva, C. (2016). The impacts of fiscal policy shocks on the US housing market. Empirical Economics, 50(3), 777-800.

Shah, C., \& Ghonasgi, N. (2016). Determinants and forecast of price level in India: a VAR framework. Journal of Quantitative Economics, 14(1), 57-86.

Shi, J., Wang, Y., \& Wu, W. (2016). The crowding-out effect of real estate markets on corporate innovation: evidence from China. Asian Finance Association (AsianFA) 2016 Conference.

Tomura, H. (2010). International capital flows and expectation-driven boom-bust cycles in the housing market. Journal of Economic Dynamics and Control, 34(10), 1993-2009.

Wang, J., \& Zhu, J. (2018). Can labor protection promote the high-educated employee's innovation? Management World, 34(3), 139-152,166,184

Wang, L. P. (2013). An empirical study on the influencing factors of "conservatism" of real estate price in China. Management World, 10, 184-185.

Wang, M., \& Huang, Y. (2013). The effect of home purchase restriction and property tax on housing price: based on longterm dynamic equilibrium analysis. The Journal of World Economy, 36(1), 141-159.

Wang, Y., \& Zhao, J. (2015). Hedge funds and corporate innovation. Financial Management, 44(2), 353-385.

Wu, J., Gyourko, J., \& Deng, Y. (2012). Evaluating conditions in major Chinese housing markets. Regional Science and Urban Economics, 42(3), 531-543.

Yu, Y., \& Zhang, S. (2017). Urban housing prices, purchase restriction policy and technological innovation. China Industrial Economics, 6, 100-118.

Zhang, H., Yuan, X., Chen, Z., \& Guo, H. (2011). An empirical analysis of the impact of investment demand on housing prices in China. Soft Science, 25(3), 24-30.

Zhang, J., Yang, L. X., \& Xin, F. (2016). Does real estate impede innovation in China? An explanation based on the loan term structure in the financial system. Management World, 5, 64-80.

Zhang, S., Hou, C., \& Chen, J. (2019). Homeownership, city integration, and the sense of happiness of migrants in urban China. Frontiers of Business Research in China, 13(1), 1-20.

Zhou, L., Zhao, Y., \& Li, L. (2013). Resource misallocation and political cycles. Journal of Financial Research, 3, 15-29.

\section{Publisher's Note}

Springer Nature remains neutral with regard to jurisdictional claims in published maps and institutional affiliations.

\section{Submit your manuscript to a SpringerOpen ${ }^{\circ}$ journal and benefit from:}

- Convenient online submission

- Rigorous peer review

- Open access: articles freely available online

- High visibility within the field

- Retaining the copyright to your article

Submit your next manuscript at $\boldsymbol{\nabla}$ springeropen.com 